\title{
Work Norms and the Welfare State
}

\author{
Giacomo Corneo*t* \\ *Free University of Berlin, CEPR, London, CESifo, Munich \\ IZA, Bonn \\ *Department of Economics, Free University of Berlin, Boltzmannstr. 20, 14195 Berlin, \\ Germany. e-mail: giacomo.corneo@fu-berlin.de
}

\begin{abstract}
Many European countries still provide their citizens with social insurance programs of unprecedented generosity. A cultural critique of the welfare state contends that generous social insurance has detrimental effects on work norms. This article revisits the model of endogenous work ethic developed by Lindbeck and Nyberg and explores survey evidence on the relationship between social spending and pro-work attitudes. Both theoretical and empirical support of the cultural critique to the welfare state are found to be fragile. Furthermore, the empirical relationship between individual work ethic and individual income is shown to be non-monotonic, suggesting that weaker work norms needs not harm economic performance. (JEL code: H2)
\end{abstract}

Keywords: welfare state, work ethic, symbolic values, social insurance

\section{Introduction}

Modern welfare states came into existence following the extension of the franchise and in the wake of the first world war. They had three main components: social insurance programs, covering the risks of old age, sickness, and unemployment; governmental provision of education and health care; and progressive income taxation. Altogether, those arrangements entailed a fundamental change in the rules of the game of human life. In particular, social insurance egregiously substituted for the vanishing solidarity of the extended family network and hugely improved upon traditional assistance in form of poors' relief offered by churches and municipalities. The new welfare states alleviated the social burdens of structural economic change and contributed to a more even distribution of the fruits of scientific and technical progress.

The late 1960s and the 1970s witnessed a tremendous expansion of the welfare state in most advanced economies, one that to many observers seemed an excessive one. Social insurance came to cover a number of additional risks and the level of social benefits dramatically increased. Warnings that social policy may have gone too far multiplied. Economists used to stress two problems. First, to the extent that social reforms were financed by higher payroll taxes, they warned that labor costs would increase, thereby reducing labor demand and generating 
even more unemployment. Second, by combining higher transfers for those outside work and higher wage taxes for those in work, the expansion of the welfare state was predicted to weaken the incentives for households to supply labor, with a negative impact on output and public finances.

Following the welfare state expansion of the 1970s, a whole body of research investigated the incentive costs of tax-transfer systems, both theoretically and empirically. While several issues are still unresolved, many public economists seem to have subscribed to a mildly optimistic view of the welfare state, according to which, provided it is well designed, a welfare state with generous social insurance may be worthwhile despite the incentive costs that it generates in the labor market. This view grounds on the finding that empirically moderate reactions of labor supply-very moderate along the intensive margin and less so along the extensive margin - to taxes and transfers may rationalize rather generous redistributive schemes once you are ready to concede that individuals are quite risk averse and have strong preferences for income equality.

There is, however, a big issue that is ignored by that optimistic assessment: generous social insurance may seriously undermine the work ethic of the population. When social insurance expanded about 40 years ago, workers were imbued with the doctrine that work is a duty as long as you are physically and mentally able to work. This may explain why major increases in social transfers and wage taxes had limited effects on labor supply. However, values and attitudes toward work can change from one generation to the next. Falling returns to work as compared to living on transfers are likely to diminish the incentives for parents to instill in their children a belief that work is a duty, namely lack of self-reliance is something one has to be ashamed of. Such a slow-moving cultural change may eventually destroy pro-work values and attitudes.

If correct, the cultural critique of the welfare state sketched above has far-reaching policy implications. Governments of countries with generous social insurance programs should partly dismantle them before the whole system breaks down. Emerging economies, which can by now afford to install a Western-European-style welfare state, should refrain from doing so as the only viable model in the long run is one close to a laissez-faire economy.

The objective of this article is to scrutinize both the theoretical and empirical validity of the cultural critique to generous social insurance. Section 2 offers a brief overview of the literature on the effects of the welfare state on the work norms endorsed by the population. Section 3 revisits in some detail the main model of endogenous work norms, the one developed by Lindbeck and Nyberg (2006). I exhibit circumstances under which that model predicts that the amount of redistribution by the welfare state has a positive effect on the work ethic. In Section 4, I turn to the 
data. I show how self-reported work ethic has evolved in several OECD countries during the last three decades and obtain some novel econometric results about the effect from social insurance. The empirical evidence provides a rather weak support of the cultural critique to the welfare state. Section 5 extends the empirical exercise to assess whether a stronger work ethic leads to higher productivity at the individual level. Surprisingly, too strong a work ethic is found to be harmful for economic success. Section 6 concludes.

\section{Literature}

Modeling the effect of the welfare state on work norms is not straightforward since the concept of work norm does not belong to the standard toolkit of economists. The existing literature has developed models of the work ethic understood as a norm dictating self-supportiveness, i.e. persons who are able to work should work so as to support themselves by their own work and they should not rely on support by others, e.g. the government. Violation of that norm is assumed to generate a disutility, both because of feelings of guilt and because of social sanctions associated with one's loss of reputation. The main idea is that the stronger the work ethic endorsed by people, the larger is the utility loss from breaking the work norm.

In Lindbeck (1997) and Lindbeck et al. (1999, 2003), the disutility from deviation from the work norm is simply assumed to decrease with the share of transfer recipients. ${ }^{1}$ Transfer recipients may either be people who cannot work or people who choose to live off the welfare state. Since transfer recipients may be individuals who themselves break the norm, those models exhibit the critical-mass effect popularized by Shelling (1971). The larger the share of the population that violates the norm, the smaller the utility loss from violating it, and the stronger the incentive to live off handouts from the government. Thus, there can be both an equilibrium with large norm compliance and large individual costs in case of deviating from the norm, and one where the norm breaks down in terms of both behavior and social sanctions. In such a framework, an exogenous increase in the generosity of the welfare state or a sudden deep recession may eliminate the good equilibrium and lead to the collapse of the work norm and the welfare state itself.

A main contribution of the papers quoted above is to model the generosity of the welfare state as the outcome of a political process. This can eliminate equilibrium multiplicity. Lindbeck et al. (1999) show that under

1 See also Lindbeck (1995a, b). 
majority voting there exists at most one equilibrium: either a laissez-faire one, supported by a majority of potential taxpayers, or one with a generous welfare state, supported by a majority of transfer recipients. The laissez-faire equilibrium is one where the norm is vastly obeyed and the work ethic is strong, whereas the work ethic is weak in the welfare-state equilibrium.

In the papers discussed above, the modeling of the work ethic is rather crude. The work norm is formally equivalent to a network externality where the utility from adopting the 'good behavior' increases with the share of adopters. This is not very satisfactory in view of the evaluative stance associated with the work ethic. That dimension of norms was already stressed by Akerlof (1980) who in his theory of social custom posited that the disutility from breaking the norm increases with the share of those who believe in the norm. ${ }^{2}$ Moreover, neither Akerlof's model of social custom nor the above models of work norms can explain the existence of the norm; they can only explain its stability and intensity.

Microfoundations for the existence of a work norm have been proposed by Lindbeck and Nyberg (2006). Their approach will be presented in some details in the next Section. Its distinctive trait is to model work norms as the outcome of a purposive socialization process by which parents raise their children to work hard. The underlying idea is that it is in the parents' interest to instill a work ethic in their children so as to prevent children's free-riding on parents' altruism. The existence of work norms is explained by parents' incentive to counteract their children's opportunism.

The welfare state may affect the incentive for parents to instill a work norm. Lindbeck and Nyberg (2006) analyze the case of a social insurance program that redistributes income among all children, once they have become adults. If social insurance supports children without own market income, some of the costs of children's free riding are shifted from the parents to the government, so that the incentive for the parents to instill a work norm diminishes. However, the redistributive effect of social insurance further distorts downwards the effort of children, which might worsen the conflict of interest between parents and children and lead parents to instill a stricter work ethic. Lindbeck and Nyberg exhibit circumstances under which the first effect prevails and a more generous social insurance reduces the work ethic. ${ }^{3}$

2 In turn, the share of believers was assumed to increase if in the previous period the share of those who complied with the norm was larger than the share of those who believed in the norm.

3 Differently from the models mentioned above, in the current one the welfare state is exogenous. There is a constant marginal tax rate and a benefit for those out of work such that the government's budget is balanced. 
Two theoretical papers spurred by Lindbeck and Nyberg (2006) are Corneo (2011) and Gradstein (2010). Both papers deal with the link between social insurace and work ethic but they do not view the conflict between parents and children as key. Rather, they posit aligned interests and stress parents' incentives to instill values that favor a way of behaving that is likely to confer esteem and self-respect upon their children. Corneo (2011) is concerned with rentier states that mainly redistribute their oil revenues through unproductive jobs in the public sector. These are often countries where pro-work attitudes are relatively weak. A simple model shows that the work ethic can be strengthened if that inefficient method of redistributing the oil rent is replaced by a social inheritance given to every citizen entering adulthood.

Gradstein's (2010) model is motivated by the observation that across countries, social insurance and governmental involvement in education are highly correlated. This suggests that public education may be an optimal response to the underinvestment in human capital associated with social insurance. Gradstein's model shows that with endogenous work norms, education subsidies may also help to alleviate the deterioration of those norms. Hence, countries with larger social insurance may not have a weaker work ethic if they manage to have more generous education policies.

So far, there has not been much empirical research trying to assess the effect of the welfare state on the work ethic of the population. Two main empirical strategies have been tried. One strategy is to measure the work ethic of individuals indirectly, trying to infer it from their behavior, e.g. their labor supply. This is the approach followed by Mulligan (1997), who examines welfare participation in the USA, and Ljunge (2010), who analyzes the take up of sick leave benefits in Sweden. Both papers exhibit findings that are consistent with the view that generous social insurance tends to erode the work ethic of the population. The main problem of this approach is the impossibility to exclude that the observed behavioral changes be caused by non-observable factors other than work norms.

The other strategy consists of measuring the work ethic directly by means of survey questions. This is the approach followed by Lindbeck and Nyberg (2006) who use data from the World Value Surveys. For a subset of OECD countries, they find a negative correlation between a self-reported pro-work attitude and the share of social expenditure to GDP. Also this approach, which will be pursued in Section 4, is not without difficulties. One is the lack of uniformity in survey design and administration across countries, which hampers cross-country comparisons. Furthermore, respondents may tend to answer according to what is perceived as 'politically correct'. They may also report attitudes that are 
congruent with their work situation, just in order to reduce cognitive dissonance. ${ }^{4}$

While this article concentrates on the effect of the welfare state on the work ethic, a related issue which has received some attention in the literature is the effect of the welfare state on benefit morale, i.e. refraining from claiming government benefits to which one is not entitled. In a study based on data from the World Value Surveys, Heinemann (2008) reports that an increase in the social benefits over the preceding 20 years is associated with lower benefit morale today; he also finds that later birth cohorts have lower levels of benefit morale. The latter finding has, however, been disputed by Halla et al. (2010).

\section{The Lindbeck-Nyberg model}

I now revisit in some detail the main model of endogenous work norms, the one developed by Lindbeck and Nyberg (2006). That paper exhibits circumstances under which the amount of governmental redistribution dampens the work ethic of the population; in this way, it offers a rationale for a cultural critique of the welfare state.

\subsection{Assumptions and main result}

The model by Lindbeck and Nyberg portrays a population of families, each formed by a parent (she) and a child (he). The parent has an exogenous income and cares about own consumption and her child's utility. The parent's utility reads

$$
U_{p}=\ln c_{p}+\alpha U_{k}
$$

The parent can donate some of her exogenous income $I$ to her child. The child does not care about the utility of the parent. The child exerts effort which determines the probability to be successful in the labor market. There are two possible labor market outcomes: the high wage $w^{h}$ and the low wage $w^{l}$ (possibly zero). The child cares about own effort, consumption, and shame:

$$
U_{k}=\ln c_{k}-v(p)-d_{k} s,
$$

where $p$ is both the effort level and the probability to succeed in the labor market, $v(p)=-q \ln (1-p)$ is increasing and convex, $q>0$ is a parameter, and $d_{k}$ equals 1 if the child turns out to fail in the labor market and it 4 An account of critical issues when using subjective survey data is offered by Bertrand and
Mullainathan (2001). 
equals 0 otherwise. Variable $s \geq 0$ stands for the shame level in case of not being self-reliant and captures the work ethic of the child.

The sequence of events is as follows: first, the parent transmits a work ethic $s$; second, the child exerts effort; third, Nature determines the child's wage; fourth, wages are redistributed according to a balanced social insurance scheme; fifth, the parent chooses how much income to donate to her child. Social insurance has a constant marginal tax rate $t$ and a benefit $B$ for those who failed in the labor market. Those two parameters are related through the government's budget constraint:

$$
t\left[\pi w^{h}+(1-\pi) w^{l}\right]=(1-\pi) B,
$$

where $\pi$ is the fraction of individuals in the good state. In case of ex-ante identical families, $\pi=p$ ex post.

In this model, the child anticipates the help of his parent and therefore exerts less effort than in her absence. Between the parent and the child there is a divergence of interests with respect to the level of effort: the parent prefers a higher level of effort than her child. This feature hinges on the one-way altruism assumption. For both the child and the parent, the marginal cost of effort is given by its marginal disutility $v^{\prime}$. The marginal benefit from higher effort depends on how much it raises the expected utility from consumption by increasing the probability to switch from the bad state to the good state. For the child, that utility differential only includes the difference in own utility from own consumption. For the altruist parent, it includes both the child's difference in utility and the one due to the change in own consumption. Hence, as soon as the parent's consumption in the good state is higher than in the bad state-which is the case as soon as the parent's gift is larger in the bad state than in the good state - the parent prefers a higher level of effort than the amount chosen by her child. It is this conflict of interest which may make the parent willing to harm her child by instilling a shame level $s>0$ for failure in the labor market: the larger $s$, the larger the utility differential between good and bad states and the greater the child's effort.

The optimal level of work ethic $s$ from the parent's perspective weights its incentive effect against the child's expected utility loss from feeling more shame. The parent only instills a strictly positive amount of work ethic if the child's effort choice is much lower than the parent's preferred level. Poor parents who donate nothing to their children even in case of a low wage do not prefer a higher effort and therefore set $s$ equal to zero. The same lack of work ethic obtains if the income of the parent is so low that she only donates a little bit, since the effort distortion has a second-order effect. Sufficiently rich parents with large gifts to children set instead $s>0$. 
Social insurance decreases the income received in the good state by the child and it increases the income he receives in the bad state. As long as some inequality persists, it remains true that parents prefer a higher level of effort than their children. However, social insurance changes the amount donated by parents to their children. Children with bad outcomes receive less and children with good outcomes receive more. Hence, social insurance indirectly reduces also consumption inequality among all parents. $^{5}$

The main result in Lindbeck and Nyberg (2006) is about the comparative statics of the work ethic associated with a marginal change in the tax rate under budget-balanced social insurance:

Proposition 1: Assume that, in equilibrium, all parents financially support their children even when the latter earn the high wage. Then, a marginal increase of the tax rate leads to a weaker work ethic $(d s / d t<0)$.

Proof: see the proof of Proposition 4 in Lindbeck and Nyberg (2006).

This result may be interpreted as demonstrating the existence of a long-term negative effect of the welfare state on work incentives. If parents correctly anticipate that their children's social insurance will be more redistributive, they will instill weaker work norms. A reform that makes social insurance today more generous and that is permanent may have small effects on incentives today, because the work ethic of the current generation is already fixed and more redistribution by the government is partly outdone by less redistribution by parents. However, more generous social insurance may have large effects on future work norms because the values of the next generation have not crystallized yet. Thus, the long-run costs of the welfare state in terms of foregone GDP may be much larger than commonly thought.

\subsection{An additional result}

The main result in Lindbeck and Nyberg (2006) applies to parameter constellations such that in equilibrium parents give a financial aid to their children both in the case of failure in the labor market and in the

5 Notice that parents' incomes are not directly affected by social insurance in this model. This is not very satisfactory if one sees this model as a shortcut for a dynamic one where also the children will have their own children. In such an encompassing model, the income of parents will be more equally distributed if there is a social insurance scheme. This would have distinctive effects on parents' incentives to instill a work ethic (it may be conjectured that rich parents instill more work ethic if they are less rich and poor parents instill more work ethic if they are less poor). 
case of success. For parameter constellations such that parents only support children with a low wage, the following fact can be established.

Proposition 2: Assume that, in equilibrium, only children who fail in the labor market receive a financial aid from their parents. If the tax rate is sufficiently close to the one that maximizes tax revenue, a marginal increase of the tax rate leads to a stronger work ethic $(d s / d t>0)$.

Proof: see the Appendix A.

In order to understand this result, it is useful to separate the effect of higher taxes from that of a higher benefit. So, suppose that the budgetary consequences of $d t>0$ or $d B>0$ merely affect the governmental provision of a public good that enters separately the utility function. If only the benefit is increased, the utility differential between the two states decreases and the child exerts less effort. Also the altruistic parent desires a lower effort level. However, since in equilibrium the parent is only donating in case of the bad state, this effect is stronger for the parent than for the child: the decrease in the effort desired by the parent is larger than the decrease in the effort chosen by the child. Then, it is optimal for the parent to diminish the level of shame inflicted upon the child in case of bad luck. As a result, a larger benefit brings about a weaker work ethic. In case of a tax-rate increase, the effect is instead stronger for the child than for the parent, since the parent is not donating in case of the good state. Thus, the parent optimally increases the level of shame so as to counteract the disincentive effect from heavier taxation: a higher tax rate brings about a stronger work ethic.

In the neighborhood of the tax rate that maximizes the tax revenue, a marginal increase of the tax rate has no first-order effect on the benefit in a budget-balanced social insurance scheme. Therefore, a more redistributive social insurance influences the work ethic only through the tax-rate effect, which is to say that it strenghtens the work ethic.

\section{Work ethic and social spending in the data}

The World Values Survey and the European Values Study-hereafter jointly referrred to as WVS - constitute a rich source of information about endorsed values. The WVS covers a large number of countries since 1981 and has been conducted in six waves. The work ethic of respondents can be captured by their answers to a survey question that has been asked in all six waves, which allows one to examine its evolution over a time span of almost three decades. The survey question reads: "Here is a list of qualities that children can be encouraged to learn at home. 
Which, if any, do you consider to be especially important? Please choose up to five.' One of the qualities in the list is 'Hard work'. This allows one to construct a dummy variable that takes value 1 if the respondent mentioned hard work as important and 0 otherwise. In the following, I call that variable 'Hard work' and intrepret it as an indicator of a strong work ethic. That variable is the same one that Lindbeck and Nyberg (2006) employed in the empirical part of their paper.

\subsection{Evolution of self-reported work ethic}

Has the work ethic of the population eroded in countries that experienced a substantial expansion of the welfare state until the late 1970s? Figures 1-4 plot the shares of pro-work respondents in four groups of countries as inferred from the WVS question mentioned above. Apparently, there is no sign of a declining work ethic in any of those countries. Since 1981, the share of those who believe hard work to be important has been rather stable or it has increased, like in Italy and the Anglosaxon countries.

The pattern exhibited by Figures 1-4 remains largely unchanged if one looks at distinctive population subgroups. Thus, while the male population consistently displays a larger share of pro-work respondents than the female population, the evolution of the work ethic since the 1980s has been very similar for men and women. Also across age groups and education levels, the evolution of self-reported work ethic in each country has been very similar to the evolution observed for its entire population.

It is noteworthy that the shares of pro-work respondents widely differ across countries. For instance, the share in France is about twice as large as the share in Germany. Arguably, such differences do not mirror real differences in average attitudes; rather, they may be mainly due to the translation of the expression 'Hard work' in the various languages. Thus, while Germans are asked about the value of 'Hart arbeiten', French are asked about 'L'application au travail', which has a much less severe connotation. ${ }^{6}$ While using the variable 'Hard work' to compare the strength of work norms across countries can be misleading, that variable proves helpful in order to assess the evolution of work norms within countries over time.

6 Another example is Portugal, a country with a very high share of pro-work respondents. There, people are asked about the value of 'Ser trabalhador', which suggests diligence and caring about work rather than hard working. 


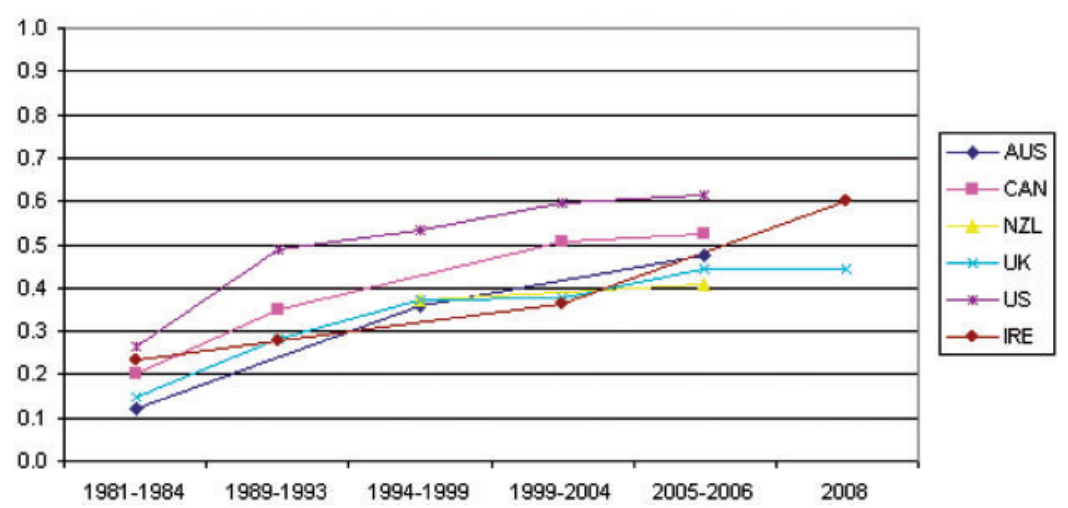

Figure 1 Share of respondents who emphasize hard work in Anglosaxon countries.

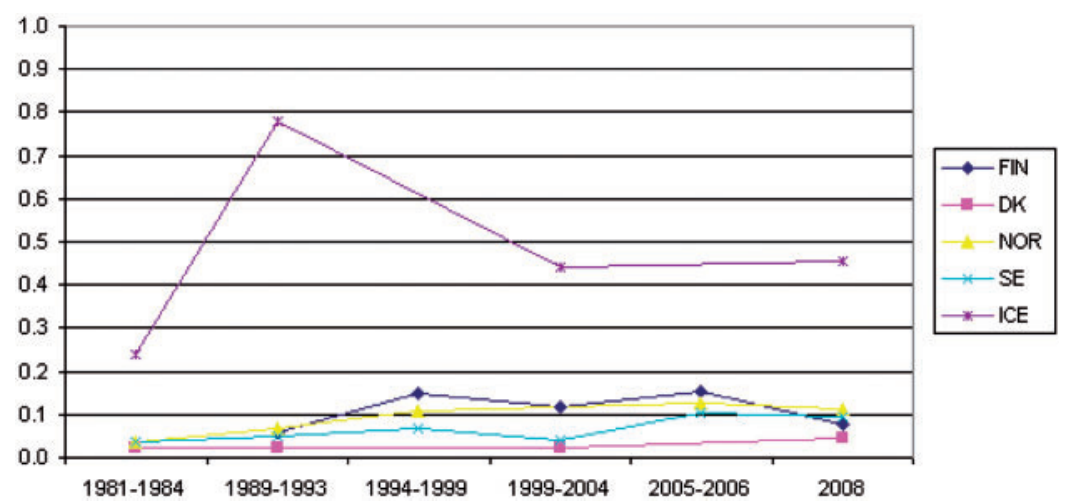

Figure 2 Share of respondents who emphasize hard work in Nordic countries.

\subsection{Regression analysis}

I focus on OECD countries. ${ }^{7}$ The WVS data can be combined with aggregate country data to investigate whether changes in the generosity of social insurance correlate with country-specific changes in the strength of the work ethic. In what follows, individual work attitudes measured by the

7 All countries that are current members of the OECD are included in the regressions, with the exception of Hungary and Poland. For those two countries, the survey item capturing the work ethic seems to suffer from a serious problem of inconsistent wording or inaccurate coding across waves. I have also excluded from the last wave Turkey because the hard-work variable is clearly unreliable (it equals 1 for all respondents). 


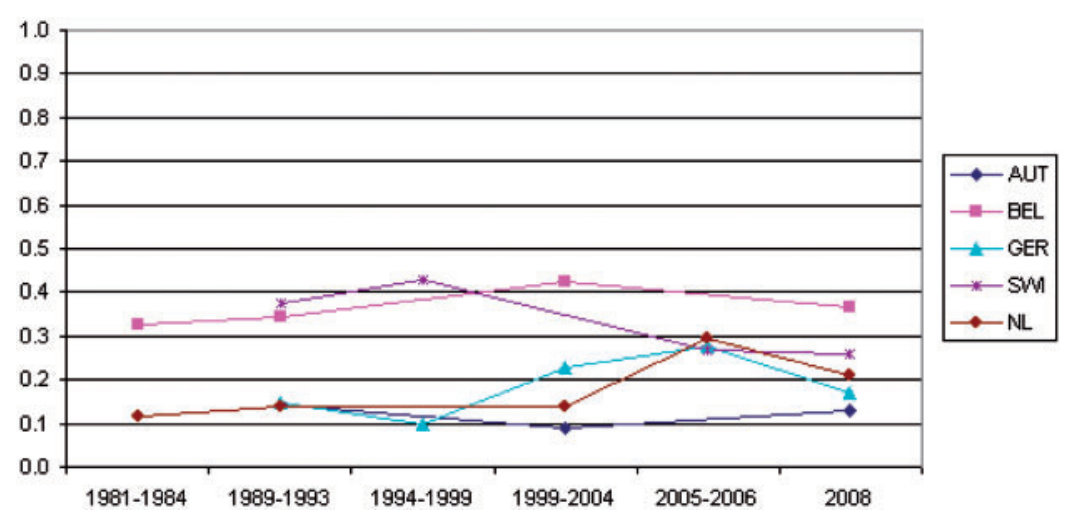

Figure 3 Share of respondents who emphasize hard work in Continental European countries.

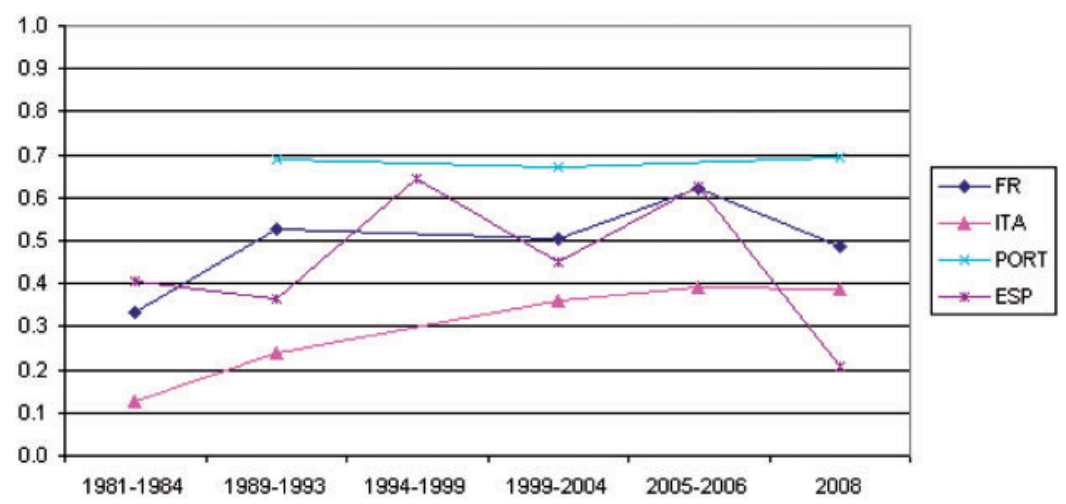

Figure 4 Share of respondents who emphasize hard work in Southern European countries.

dummy variable 'Hard work' are regressed on social expenditure as a percentage of GDP in the respondent's country in the year of the survey.

Estimation results for four logit regressions are reported in Table 1. All specifications include an unreported constant as well as unreported country-dummies that control for highly significant unobserved countryspecific factors. Standard errors are adjusted for clustering by country of the respondent. ${ }^{8}$ The first regression only includes as individual controls the respondent's age, gender, family status and whether the respondent's household includes children. The second equation adds the respondent's

8 See Moulton (1990). 
Table 1 Binary logit regressions for the emphasis on hard work

\begin{tabular}{|c|c|c|c|c|}
\hline & (1) & (2) & (3) & (4) \\
\hline Social spending/ GDP & $\begin{array}{l}0.060^{*} \\
(2.16)\end{array}$ & $\begin{array}{c}0.028 \\
(0.57)\end{array}$ & $\begin{array}{l}-0.010 \\
(-0.12)\end{array}$ & $\begin{array}{l}-0.040 \\
(-0.82)\end{array}$ \\
\hline Age & $\begin{array}{l}0.016^{* * *} \\
(3.46)\end{array}$ & $\begin{array}{c}0.001 \\
(0.29)\end{array}$ & $\begin{array}{c}0.001 \\
(0.13)\end{array}$ & $\begin{array}{c}0.002 \\
(0.31)\end{array}$ \\
\hline Age squared & $\begin{array}{l}-0.000 \\
(-0.44)\end{array}$ & $\begin{array}{r}0.000 \\
(1.62)\end{array}$ & $\begin{array}{r}0.000 \\
(1.45)\end{array}$ & $\begin{array}{r}0.000 \\
(1.31)\end{array}$ \\
\hline Female & $\begin{array}{l}-0.290^{* * *} \\
(-6.95)\end{array}$ & $\begin{array}{l}-0.337^{* * *} \\
(-7.58)\end{array}$ & $\begin{array}{l}-0.345^{* * *} \\
(-6.78)\end{array}$ & $\begin{array}{l}-0.352^{* * *} \\
(-6.82)\end{array}$ \\
\hline Legal status & & & & \\
\hline - married & $\begin{array}{l}-0.024 \\
(-0.64)\end{array}$ & $\begin{array}{l}-0.010 \\
(-0.29)\end{array}$ & $\begin{array}{l}-0.004 \\
(-0.12)\end{array}$ & $\begin{array}{l}-0.019 \\
(-0.48)\end{array}$ \\
\hline - divorced & $\begin{array}{l}-0.112^{* *} \\
(-2.80)\end{array}$ & $\begin{array}{l}-0.096 \\
(-1.94)\end{array}$ & $\begin{array}{l}-0.092 \\
(-1.66)\end{array}$ & $\begin{array}{l}-0.101 \\
(-1.71)\end{array}$ \\
\hline - widowed & $\begin{array}{c}0.035 \\
(0.63)\end{array}$ & $\begin{array}{c}0.044 \\
(0.80)\end{array}$ & $\begin{array}{c}0.050 \\
(0.82)\end{array}$ & $\begin{array}{c}0.042 \\
(0.61)\end{array}$ \\
\hline Children & $\begin{array}{l}-0.021 \\
(-0.43)\end{array}$ & $\begin{array}{r}0.049 \\
(1.10)\end{array}$ & $\begin{array}{r}0.050 \\
(1.09)\end{array}$ & $\begin{array}{c}0.050 \\
(1.11)\end{array}$ \\
\hline Primary income source & & & & \\
\hline - Part time work & & $\begin{array}{c}0.006 \\
(0.12)\end{array}$ & $\begin{array}{c}-0.003 \\
(-0.06)\end{array}$ & $\begin{array}{l}-0.008 \\
(-0.15)\end{array}$ \\
\hline - Self-employed & & $\begin{array}{l}-0.040 \\
(-0.72)\end{array}$ & $\begin{array}{l}-0.028 \\
(-0.53)\end{array}$ & $\begin{array}{l}-0.036 \\
(-0.59)\end{array}$ \\
\hline - Retired & & $\begin{array}{l}-0.021 \\
(-0.44)\end{array}$ & $\begin{array}{c}-0.011 \\
(-0.21)\end{array}$ & $\begin{array}{l}-0.021 \\
(-0.42)\end{array}$ \\
\hline - Housewife & & $\begin{array}{r}0.041 \\
(0.82)\end{array}$ & $\begin{array}{r}0.024 \\
(0.46)\end{array}$ & $\begin{array}{r}0.043 \\
(0.77)\end{array}$ \\
\hline - Student & & $\begin{array}{l}-0.018 \\
(-0.37)\end{array}$ & $\begin{array}{c}-0.055 \\
(-0.99)\end{array}$ & $\begin{array}{c}-0.057 \\
(-1.02)\end{array}$ \\
\hline - Unemployed & & $\begin{array}{l}-0.033 \\
(-0.62)\end{array}$ & $\begin{array}{l}-0.064 \\
(-1.17)\end{array}$ & $\begin{array}{l}-0.080 \\
(-1.51)\end{array}$ \\
\hline - Other & & $\begin{array}{l}-0.116 \\
(-1.27)\end{array}$ & $\begin{array}{c}-0.184 \\
(-1.95)\end{array}$ & $\begin{array}{l}-0.154^{*} \\
(-2.39)\end{array}$ \\
\hline Education & & & & \\
\hline - Primary education & & $\begin{array}{l}-0.164 \\
(-1.95)\end{array}$ & $\begin{array}{l}-0.149 \\
(-1.72)\end{array}$ & $\begin{array}{l}-0.158^{*} \\
(-2.08)\end{array}$ \\
\hline - Some secondary education & & $\begin{array}{l}-0.331^{* * *} \\
(-3.94)\end{array}$ & $\begin{array}{l}-0.315^{* * *} \\
(-3.58)\end{array}$ & $\begin{array}{l}-0.323^{* * *} \\
(-3.76)\end{array}$ \\
\hline - Secondary education & & $\begin{array}{l}-0.413^{* * *} \\
(-5.26)\end{array}$ & $\begin{array}{l}-0.411^{* * *} \\
(-4.83)\end{array}$ & $\begin{array}{l}-0.414^{* * *} \\
(-4.73)\end{array}$ \\
\hline - Tertiary education & & $\begin{array}{l}-0.402^{* * *} \\
(-3.78)\end{array}$ & $\begin{array}{l}-0.390 * * * \\
(-3.47)\end{array}$ & $\begin{array}{l}-0.398^{* * *} \\
(-3.98)\end{array}$ \\
\hline Income inequality & & & $\begin{array}{l}0.117 \text { *** } \\
(3.86)\end{array}$ & $\begin{array}{l}0.101^{* * * *} \\
(2.74)\end{array}$ \\
\hline Log real GDP per capita & & & $\begin{array}{r}0.337 \\
(0.41)\end{array}$ & $\begin{array}{l}3.461^{*} \\
(2.44)\end{array}$ \\
\hline Unemployment rate & & & $\begin{array}{l}-0.016 \\
(-0.55)\end{array}$ & $\begin{array}{r}0.072 \\
(1.54)\end{array}$ \\
\hline Real GDP growth rate & & & $\begin{array}{l}-0.063 \\
(-1.16)\end{array}$ & $\begin{array}{l}-0.086 \\
(-1.80)\end{array}$ \\
\hline Country dummies & Yes & Yes & Yes & Yes \\
\hline Year dummies & No & No & No & Yes \\
\hline Observations & 124969 & 77821 & 69138 & 69138 \\
\hline
\end{tabular}

$t$-Statistics in parentheses: ${ }^{*} P<0.05,{ }^{* *} P<0.01,{ }^{* * *} P<0.001$.

CESifo Economic Studies, 2012 
job status and educational attainment-two variables that may be endogenous to the respondent's work ethic. The third equation adds the following macroeconomic controls: the Gini coefficient of the distribution of household adult-equivalent net income, the natural logarithm of per-capita GDP in real terms, the unemployment rate, and the annual growth rate of real GDP. ${ }^{9}$ The fourth specification adds year fixed effects for the year in which the survey was conducted.

Table 1 provides an insight into the effect from country-specific changes in the generosity of social insurance over time on the work ethic of individuals living in that country. The relative size of social insurance has some explanatory power of the work ethic of individuals in the first regression, but the estimated coefficient has the wrong sign: increases in social expenditure come together with a wider endorsement of work norms. Including additional individual controls and macroeconomic controls makes the estimated coefficients on the social insurance variable statistically insignificant. If one additionally controls for the year when the survey was conducted, a coefficient with the expected sign obtains. However, the coefficient is not significant at the $10 \%$ level. ${ }^{10}$

In columns (2)-(4) of Table 1, about $40 \%$ of the sample is lost because of missing information about respondents' education. Specifically, educational attainment is almost entirely missing from the first two waves of the WVS. In order to keep those observations in the regressions, I have adopted specifications that replicate those in Table 1 but drop the education dummies and instead include year fixed effects. Results are shown in Table 2. Social expenditure carries a negative coefficient but its effect is very small and not significant.

Restricting the sample to the Anglosaxon and the Western-European countries does not produce qualitatively different results. Also replacing current social expenditure with social expenditure 10 or 20 years before the survey was conducted does not yield statistically significant results. Possibly, social expenditure as a share of GDP is not a good proxy of the generosity of the welfare state. Thus, I also tried to replace it with an index of generosity calculated by political scientists for a subset of OECD countries. ${ }^{11}$ Results remained qualitatively similar to those reported in the tables here.

9 The Gini coefficients are taken from the Standardized World Income Inequality Database, while the remaining macro variables are OECD data.

10 Household income is not controlled for in the regressions of Table 1 because income should be endogenous to the work ethic, see Section 5, and because plenty of observations are missing. Adding household income to the regression equations in Tables 1 and 2 leaves the results about the effect from social expenditure qualitatively unaffected.

11 See Scruggs and Allan (2006). Their generosity index captures the ratio of the after-tax benefit payable to a typical worker to that worker's after-tax wage. 
Table 2 Binary logit regressions for the emphasis on hard work

\begin{tabular}{|c|c|c|c|}
\hline & (1) & (2) & (3) \\
\hline Social spending/ GDP & $\begin{array}{l}-0.002 \\
(-0.10)\end{array}$ & $\begin{array}{l}-0.005 \\
(-0.21)\end{array}$ & $\begin{array}{l}-0.009 \\
(-0.28)\end{array}$ \\
\hline Age & $\begin{array}{l}0.016^{* * * *} \\
(3.72)\end{array}$ & $\begin{array}{l}0.014 * * \\
(3.24)\end{array}$ & $\begin{array}{l}0.014 * * \\
(2.93)\end{array}$ \\
\hline Age squared & $\begin{array}{l}-0.000 \\
(-0.66)\end{array}$ & $\begin{array}{l}-0.000 \\
(-0.23)\end{array}$ & $\begin{array}{l}-0.000 \\
(-0.21)\end{array}$ \\
\hline Female & $\begin{array}{l}-0.298 * * * \\
(-6.69)\end{array}$ & $\begin{array}{l}-0.320^{* * * *} \\
(-7.62)\end{array}$ & $\begin{array}{l}-0.339^{* * *} \\
(-7.16)\end{array}$ \\
\hline Legal status & & & \\
\hline - married & $\begin{array}{l}-0.004 \\
(-0.13)\end{array}$ & $\begin{array}{l}-0.013 \\
(-0.40)\end{array}$ & $\begin{array}{l}-0.032 \\
(-1.05)\end{array}$ \\
\hline - divorced & $\begin{array}{l}-0.109 * * \\
(-2.62)\end{array}$ & $\begin{array}{l}-0.108^{* *} \\
(-2.63)\end{array}$ & $\begin{array}{l}-0.129 * * \\
(-3.01)\end{array}$ \\
\hline - widowed & $\begin{array}{c}0.075 \\
(1.32)\end{array}$ & $\begin{array}{c}0.080 \\
(1.52)\end{array}$ & $\begin{array}{c}0.067 \\
(1.18)\end{array}$ \\
\hline Children & $\begin{array}{l}0.013 \\
(0.26)\end{array}$ & $\begin{array}{l}0.016 \\
(0.33)\end{array}$ & $\begin{array}{l}0.065 \\
(1.50)\end{array}$ \\
\hline Primary income source & & & \\
\hline - Part time work & & $\begin{array}{l}-0.046 \\
(-1.22)\end{array}$ & $\begin{array}{l}-0.029 \\
(-0.80)\end{array}$ \\
\hline - Self-employed & & $\begin{array}{l}-0.031 \\
(-0.62)\end{array}$ & $\begin{array}{c}0.014 \\
(0.29)\end{array}$ \\
\hline - Retired & & $\begin{array}{l}-0.024 \\
(-0.58)\end{array}$ & $\begin{array}{l}-0.010 \\
(-0.21)\end{array}$ \\
\hline - Housewife & & $\begin{array}{c}0.041 \\
(0.76)\end{array}$ & $\begin{array}{c}0.074 \\
(1.46)\end{array}$ \\
\hline - Student & & $\begin{array}{l}-0.044 \\
(-0.85)\end{array}$ & $\begin{array}{l}-0.056 \\
(-1.00)\end{array}$ \\
\hline - Unemployed & & $\begin{array}{l}-0.016 \\
(-0.33)\end{array}$ & $\begin{array}{l}-0.017 \\
(-0.35)\end{array}$ \\
\hline - Other & & $\begin{array}{l}-0.068 \\
(-0.86)\end{array}$ & $\begin{array}{l}-0.071 \\
(-0.96)\end{array}$ \\
\hline Income inequality & & & $\begin{array}{l}0.086^{* *} \\
(2.90)\end{array}$ \\
\hline Log real GDP per capita & & & $\begin{array}{l}1.489^{* *} \\
(3.01)\end{array}$ \\
\hline Unemployment rate & & & $\begin{array}{l}0.015 \\
(0.87)\end{array}$ \\
\hline Real GDP growth rate & & & $\begin{array}{r}0.001 \\
(0.02)\end{array}$ \\
\hline Country dummies & Yes & Yes & Yes \\
\hline Year dummies & Yes & Yes & Yes \\
\hline Observations & 124969 & 122333 & 111073 \\
\hline
\end{tabular}

$t$-Statistics in parentheses: $* P<0.05, * * P<0.01, * * * P<0.001$. 


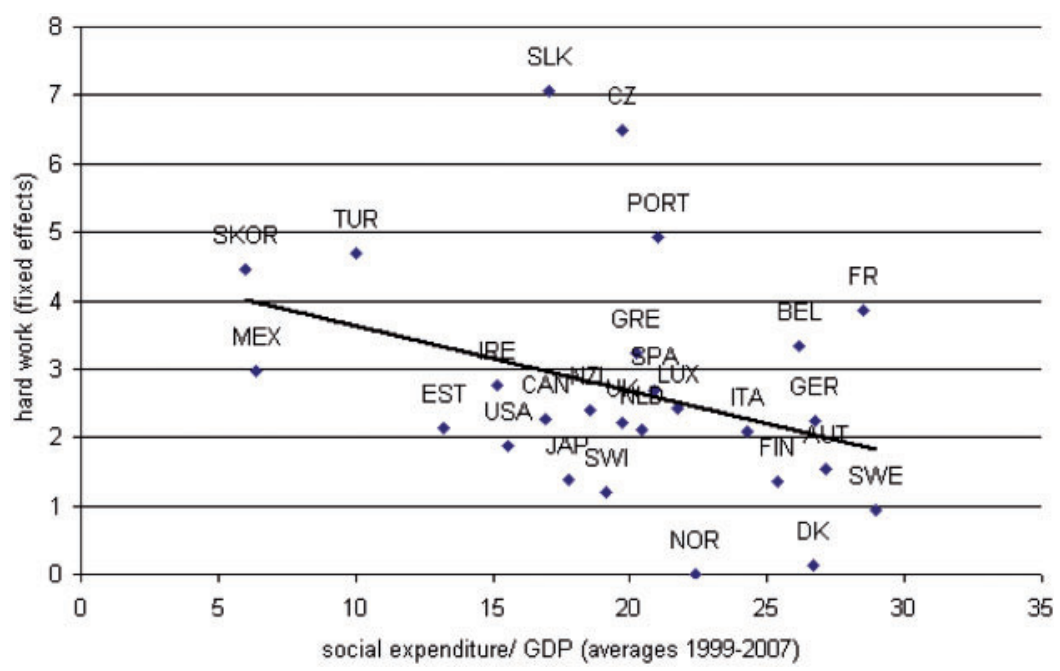

Figure 5 Emphasis on hard work and social spending in OECD countries.

Summing up, I find that survey-based evidence in support of the cultural critique of the welfare state rests on rather shaky grounds. Changes over time in the relative size and generosity of social insurance in the various countries seem to have at best a small impact on the work ethic of their populations. $^{12}$

If one uses the data to conduct a cross-country analysis, emphasis on hard work and social spending appear to be negatively correlated. Figure 5 exhibits a scatter plot of country-specific work ethic and social insurance. The work ethic of a country is proxied by the coefficient on the corresponding country dummy taken from regression (4) in Table 1. The generosity of social insurance in a country is proxied by the average ratio of social spending to GDP in that country in the period from 1999 to 2007. A possible interpretation of the pattern in Figure 5 is that it mirrors equilibrium multiplicity. Countries may be characterized by different national cultures that make them coordinate on different combinations of work norms and social insurance.

12 Lindbeck and Nyberg (2006) find instead that social spending significantly decreases the probability of mentioning hard work as an important quality. That difference is due to various differences in sample and specification. Among other things, they only use the first three waves of WVS, they eliminate former socialist countries and only consider respondents with one child, and they do not employ country dummies. If country dummies are omitted from the regressions in Tables 1 and 2 of this article, social spending carries a statistically significant negative coefficient. 


\section{The missing gain from a strong work ethic}

Interest about the effect of social insurance on the work ethic of individuals mainly derives from the presumption that individuals with a weaker work ethic contributes less to production, national income, and tax revenue. Conversely, a stronger work ethic is expected to lead individuals to devote a larger share of their time and energy to work, thereby increasing labor supply and output; individuals with a stronger work ethic are expected to expend more effort in job search and to end up receiving higher incomes and paying more taxes and contributions. The WVS data can be used to investigate to what extent that presumption is corroborated by the evidence.

The WVS only contains information about the annual household income of respondents. That income information is collected in countryspecific categories that can be used to assign each respondent to a quintile of the income distribution of that respondent's country in the year of the survey. I employ the respondent's quintile in the income distribution as a proxy for a respondent's productivity and examine how the probability of being in the various quintiles of the income distribution is affected by the respondent's work ethic.

Respondents in the early stage or in the late stage of their lifecycles often receive annual incomes that are not representative of their permanent income, which is the measure of individual productivity one is especially interested in. However, as shown by the literature on the lifecycle variation in the association between annual and lifetime income, annual income when aged between 35 and 55 is a reliable proxy of permanent income. ${ }^{13}$ Therefore, I restrict the sample to respondents in that age bracket. Furthermore, since the regressions presented in the previous Section indicate that gender has a strong effect on the self-reported work ethic, I run separate regressions for male and for female respondents. For the sake of brevity, only regressions for the male population are presented; results for the female respondents are similar.

Table 3 shows estimates from four-ordered logit regressions. All regression equations include a constant, country fixed effects and year fixed effects; standard errors are adjusted for clustering by country of the respondent. The first regression only includes as individual controls the respondent's age and family status. The second equation include dummies for the number of children in the respondent's household. The third equation adds the respondent's educational attainment and the fourth one further adds the respondent's job status.

13 See e.g. Björklund (1993), Bönke et al. (2012) and Haider and Solon (2006). 


\section{G. Corneo}

Table 3 Ordered logit regressions for income quintile of male respondents aged $35-55$ years

\begin{tabular}{|c|c|c|c|c|}
\hline & (1) & (2) & (3) & (4) \\
\hline Hard work & $\begin{array}{l}-0.171^{* * *} \\
(-3.93)\end{array}$ & $\begin{array}{l}-0.166^{* * *} \\
(-3.80)\end{array}$ & $\begin{array}{l}-0.040 \\
(-0.89)\end{array}$ & $\begin{array}{l}-0.071 \\
(-1.47)\end{array}$ \\
\hline Age & $\begin{array}{l}0.127^{* * *} \\
(4.36)\end{array}$ & $\begin{array}{l}0.152^{* * *} \\
(5.05)\end{array}$ & $\begin{array}{l}0.151^{* * * *} \\
(3.37)\end{array}$ & $\begin{array}{l}0.109^{*} \\
(2.52)\end{array}$ \\
\hline Age squared & $\begin{array}{l}-0.001^{* * *} \\
(-4.54)\end{array}$ & $\begin{array}{l}-0.002 * * * \\
(-5.14)\end{array}$ & $\begin{array}{l}-0.002^{* * * *} \\
(-3.33)\end{array}$ & $\begin{array}{l}-0.001 * \\
(-2.26)\end{array}$ \\
\hline Legal status & & & & \\
\hline - married & $\begin{array}{l}1.147^{* * *} \\
(8.85)\end{array}$ & $\begin{array}{l}1.154^{* * *} \\
(9.87)\end{array}$ & $\begin{array}{l}1.145^{* * * *} \\
(9.03)\end{array}$ & $\begin{array}{l}1.018^{* * *} \\
(8.08)\end{array}$ \\
\hline - divorced & $\begin{array}{l}0.063 \\
(0.92)\end{array}$ & $\begin{array}{c}0.053 \\
(0.66)\end{array}$ & $\begin{array}{l}0.013 \\
(0.16)\end{array}$ & $\begin{array}{r}0.027 \\
(0.35)\end{array}$ \\
\hline - widowed & $\begin{array}{c}0.102 \\
(1.01)\end{array}$ & $\begin{array}{c}0.101 \\
(0.91)\end{array}$ & $\begin{array}{c}0.128 \\
(0.89)\end{array}$ & $\begin{array}{c}0.191 \\
(1.19)\end{array}$ \\
\hline Number of children & & & & \\
\hline-1 child & & $\begin{array}{c}0.089 \\
(1.12)\end{array}$ & $\begin{array}{c}0.156 \\
(1.72)\end{array}$ & $\begin{array}{c}0.170 \\
(1.85)\end{array}$ \\
\hline-2 children & & $\begin{array}{l}0.170^{*} \\
(2.00)\end{array}$ & $\begin{array}{l}0.216^{*} \\
(2.35)\end{array}$ & $\begin{array}{c}0.182 \\
(1.93)\end{array}$ \\
\hline-3 children & & $\begin{array}{c}0.034 \\
(0.34)\end{array}$ & $\begin{array}{c}0.136 \\
(1.31)\end{array}$ & $\begin{array}{c}0.130 \\
(1.25)\end{array}$ \\
\hline - 4 or more children & & $\begin{array}{l}-0.312^{* *} \\
(-2.64)\end{array}$ & $\begin{array}{l}-0.152 \\
(-1.41)\end{array}$ & $\begin{array}{l}-0.118 \\
(-1.10)\end{array}$ \\
\hline Education & & & & \\
\hline - Primary education & & & $\begin{array}{l}0.739 * * * \\
(5.48)\end{array}$ & $\begin{array}{l}0.707 * * * \\
(4.07)\end{array}$ \\
\hline - Some secondary education & & & $\begin{array}{l}1.370^{* * *} \\
(9.30)\end{array}$ & $\begin{array}{l}1.287 * * * \\
(7.00)\end{array}$ \\
\hline - Secondary education & & & $\begin{array}{l}2.143^{* * *} \\
(14.37)\end{array}$ & $\begin{array}{l}1.996^{* * *} \\
(10.10)^{2}\end{array}$ \\
\hline - Tertiary education & & & $\begin{array}{l}2.971^{* * * *} \\
(16.32)\end{array}$ & $\begin{array}{l}2.800^{* * *} \\
(12.15)\end{array}$ \\
\hline Primary income source & & & & \\
\hline - Part time work & & & & $\begin{array}{l}-0.731^{* * *} \\
(-5.58)\end{array}$ \\
\hline - Self-employed & & & & $\begin{array}{l}-0.042 \\
(-0.72)\end{array}$ \\
\hline - Retired & & & & $\begin{array}{l}-1.162^{* * *} \\
(-7.33)\end{array}$ \\
\hline - Wife's income & & & & $\begin{array}{l}-0.959^{* * *} \\
(-3.38)\end{array}$ \\
\hline - Student & & & & $\begin{array}{l}-2.100^{* * * *} \\
(-9.67)\end{array}$ \\
\hline - Unemployed & & & & $\begin{array}{l}-1.870^{* * * *} \\
(-13.21)\end{array}$ \\
\hline - Other & & & & $\begin{array}{l}-1.584^{* * *} \\
(-6.91)\end{array}$ \\
\hline Country dummies & Yes & Yes & Yes & Yes \\
\hline Year dummies & Yes & Yes & Yes & Yes \\
\hline Observations & 27968 & 26920 & 18630 & 18154 \\
\hline
\end{tabular}

$t$-Statistics in parentheses: $* P<0.05,{ }^{* *} P<0.01,{ }^{* * *} P<0.001$. 
A respondent's work ethic is proxied by the dummy variable 'Hard work' described above. Surprisingly, a strong work ethic is found to decrease the probability of ranking high in the income distribution. The negative impact of one's work ethic on one's income is strongly significant in the regressions employed for columns 1 and 2 in Table 3. However, if one controls for a respondent's education and job status, the effect from the work ethic becomes statistically insignificant.

The last three waves of the WVS contain two additional items that can be used in order to construct two further proxies of a respondent's work ethic. They can be used to gain further insights and to check the robustness of the negative results shown in Table 3. Specifically, respondents were asked whether they agree with the following two statements: 'It is humiliating to receive money without having to work for it' and 'Work is a duty towards society'. Respondents could choose 'Strongly agree', 'Agree', 'Neither agree nor disagree', 'Disagree' or 'Strongly disagree'. From each question, one can derive dummy variables that capture the strength of the respondent's work ethic. I call 'Money-work 5' a dummy that equals one if the respondent strongly agrees with the statement that it is humiliating to receive money without having to work for it and zero otherwise; 'Money-work 4' equals one if the respondent agrees with the same statement, whereas 'Money-work 3', 'Money-work 2', and 'Money-work 1' respectively refer to 'Neither agree nor disagree', 'Disagree', and 'Strongly disagree'. In an analogous way, I construct dummies for the work ethic as inferred from answers to the question about work as a duty toward society.

Table 4 replicates the regressions of Table 3 except for replacing 'Hard work' with the proxies of the work ethic from the question about the humiliation from not being self-reliant. The reference category is the middle category 'Money-work 3'. The estimation results suggest that the relationship between the strength of the work ethic and the income level is non-monotonic: at low levels, a strengthening of the respondent's work ethic tends to increase a respondent's income, but at high levels, a further strengthening of the respondent's work ethic tends to decrease a respondent's income.

A similar pattern emerges when using the proxies derived from reactions to the statement about work as a duty toward society. Results exhibited in Table 5 suggest that both a very weak and a very strong work ethic are associated with a low income.

The interpretation of those findings is far from obvious. On the one hand, one may contend that self-reported work ethic is not a good proxy for the respondent's true work ethic. In particular, low-income respondents may fall into one of two categories: those who report a very strong work ethic to signal that they are not lazy and those who 
Table 4: Ordered logit regressions for income quintile of male respondents aged 35-55 years

\begin{tabular}{|c|c|c|c|c|}
\hline & (1) & (2) & (3) & (4) \\
\hline Money-work 1 & $\begin{array}{l}-0.161^{* *} \\
(-3.15)\end{array}$ & $\begin{array}{l}-0.171^{* * *} \\
(-3.54)\end{array}$ & $\begin{array}{l}-0.206^{* * *} \\
(-4.08)\end{array}$ & $\begin{array}{l}-0.093 \\
(-1.75)\end{array}$ \\
\hline Money-work 2 & $\begin{array}{l}-0.047 \\
(-0.93)\end{array}$ & $\begin{array}{l}-0.071 \\
(-1.57)\end{array}$ & $\begin{array}{l}-0.082 \\
(-1.84)\end{array}$ & $\begin{array}{l}-0.050 \\
(-1.00)\end{array}$ \\
\hline Money-work 4 & $\begin{array}{l}-0.032 \\
(-0.68)\end{array}$ & $\begin{array}{l}-0.035 \\
(-0.73)\end{array}$ & $\begin{array}{c}0.018 \\
(0.37)\end{array}$ & $\begin{array}{c}0.008 \\
(0.15)\end{array}$ \\
\hline Money-work 5 & $\begin{array}{l}-0.215^{* * *} \\
(-3.74)\end{array}$ & $\begin{array}{l}-0.227 * * * \\
(-4.08)\end{array}$ & $\begin{array}{l}-0.114^{*} \\
(-2.01)\end{array}$ & $\begin{array}{l}-0.127^{*} \\
(-2.31)\end{array}$ \\
\hline Age & $\begin{array}{c}0.065 \\
(1.39)\end{array}$ & $\begin{array}{c}0.080 \\
(1.73)\end{array}$ & $\begin{array}{l}0.119^{*} \\
(2.52)\end{array}$ & $\begin{array}{c}0.058 \\
(1.28)\end{array}$ \\
\hline Age squared & $\begin{array}{l}-0.001 \\
(-1.54)\end{array}$ & $\begin{array}{l}-0.001 \\
(-1.86)\end{array}$ & $\begin{array}{l}-0.001^{*} \\
(-2.46)\end{array}$ & $\begin{array}{l}-0.001 \\
(-1.05)\end{array}$ \\
\hline \multicolumn{5}{|l|}{ Legal status } \\
\hline - married & $\begin{array}{l}1.162^{* * *} \\
(7.63)\end{array}$ & $\begin{array}{l}1.075^{* * *} \\
(7.30)\end{array}$ & $\begin{array}{l}1.044^{* * *} \\
(6.67)\end{array}$ & $\begin{array}{l}0.927^{* * *} \\
(6.13)\end{array}$ \\
\hline - divorced & $\begin{array}{r}0.085 \\
(1.05)\end{array}$ & $\begin{array}{l}-0.002 \\
(-0.02)\end{array}$ & $\begin{array}{l}-0.033 \\
(-0.34)\end{array}$ & $\begin{array}{l}-0.015 \\
(-0.16)\end{array}$ \\
\hline - widowed & $\begin{array}{l}-0.081 \\
(-0.56)\end{array}$ & $\begin{array}{l}-0.171 \\
(-1.27)\end{array}$ & $\begin{array}{l}-0.034 \\
(-0.25)\end{array}$ & $\begin{array}{r}0.035 \\
(0.21)\end{array}$ \\
\hline \multicolumn{5}{|l|}{ Number of children } \\
\hline-1 child & & $\begin{array}{r}0.141 \\
(1.65)\end{array}$ & $\begin{array}{l}0.189^{*} \\
(1.98)\end{array}$ & $\begin{array}{l}0.180^{*} \\
(2.03)\end{array}$ \\
\hline-2 children & & $\begin{array}{l}0.236^{*} \\
(2.26)\end{array}$ & $\begin{array}{l}0.292^{* *} \\
(2.62)\end{array}$ & $\begin{array}{l}0.247^{*} \\
(2.19)\end{array}$ \\
\hline - 3 children & & $\begin{array}{c}0.084 \\
(0.81)\end{array}$ & $\begin{array}{l}0.239^{*} \\
(2.23)\end{array}$ & $\begin{array}{l}0.204^{*} \\
(1.96)\end{array}$ \\
\hline - 4 or more children & & $\begin{array}{l}-0.287 \\
(-1.94)\end{array}$ & $\begin{array}{r}0.014 \\
(0.10)\end{array}$ & $\begin{array}{r}0.029 \\
(0.21)\end{array}$ \\
\hline \multicolumn{5}{|l|}{ Education } \\
\hline - Primary education & & & $\begin{array}{l}0.880^{* * *} \\
(4.10)\end{array}$ & $\begin{array}{l}0.866^{* * * *} \\
(3.78)\end{array}$ \\
\hline - Some secondary education & & & $\begin{array}{l}1.633^{* * *} \\
(6.44)\end{array}$ & $\begin{array}{l}1.567^{* * *} \\
(5.66)\end{array}$ \\
\hline - Secondary education & & & $\begin{array}{l}2.385^{* * *} \\
(9.21)\end{array}$ & $\begin{array}{l}2.263^{* * *} \\
(8.19)\end{array}$ \\
\hline - Tertiary education & & & $\begin{array}{l}3.245^{* * *} \\
(11.52)\end{array}$ & $\begin{array}{l}3.103^{* * * *} \\
(10.21)\end{array}$ \\
\hline
\end{tabular}


Table 4: Continued

\begin{tabular}{|c|c|c|c|c|}
\hline & (1) & (2) & (3) & (4) \\
\hline \multicolumn{5}{|l|}{ Primary income source } \\
\hline - Part time work & & & & $\begin{array}{l}-0.792^{* * *} \\
(-6.50)\end{array}$ \\
\hline - Self-employed & & & & $\begin{array}{l}-0.099 \\
(-1.28)\end{array}$ \\
\hline - Retired & & & & $\begin{array}{l}-1.088^{* * *} \\
(-6.63)\end{array}$ \\
\hline - Wife's income & & & & $\begin{array}{l}-1.320 \\
(-3.66)\end{array}$ \\
\hline - Student & & & & $\begin{array}{l}-2.109^{* * *} \\
(-7.25)\end{array}$ \\
\hline - Unemployed & & & & $\begin{array}{l}-2.024^{* * *} \\
(-13.75)\end{array}$ \\
\hline - Other & & & & $\begin{array}{l}-1.395^{* * *} \\
(-7.42)\end{array}$ \\
\hline Country Dummies & Yes & Yes & Yes & Yes \\
\hline Year Dummies & Yes & Yes & Yes & Yes \\
\hline Observations & 13314 & 12889 & 12818 & 12758 \\
\hline
\end{tabular}

t-Statistics in parentheses: $* P<0.05, * * P<0.01, * * * P<0.001$.

report a very low work ethic to proclaim that there laziness needs not be excused. The finding that both a very strong and a very weak self-reported work ethic come along with low income may also be driven by a simple correlation between work ethic and social classes. The majority of respondents with low incomes may belong to the working class and hard work may be a distinctive value of the working class. The remaining low-income respondents may belong to what some sociologists call the underclass. This includes individuals who choose not to take jobs, who receive welfare benefits and sporadically work in the black economy, and it includes habitual criminals. Low-income respondents from the underclass may be the ones with a distinctively weak work ethic.

On the other hand, one may try to figure out channels through which a very strong work ethic could really be harmful for income generation. A first possible channel is an individual's labor supply entering a range where marginal labor productivity is negative. Individuals with a very strong work ethic may be compulsive workers whose overwork causes them health problems - ranging from exhaustion to high blood pressure - that eventually undermine their ability to generate income. A second possibility is that overwork implies less time for social interactions, including word-of-mouth communication about job and income 
Table 5 Ordered logit regressions for income quintile of male respondents aged 35-55 years

\begin{tabular}{|c|c|c|c|c|}
\hline & (1) & (2) & (3) & (4) \\
\hline Work-duty 1 & $\begin{array}{l}-0.119^{*} \\
(-2.31)\end{array}$ & $\begin{array}{l}-0.113^{*} \\
(-2.20)\end{array}$ & $\begin{array}{l}-0.055 \\
(-1.25)\end{array}$ & $\begin{array}{l}-0.035 \\
(-0.77)\end{array}$ \\
\hline Work-duty 2 & $\begin{array}{c}0.108 \\
(1.83)\end{array}$ & $\begin{array}{c}0.104 \\
(1.69)\end{array}$ & $\begin{array}{l}0.136^{*} \\
(2.40)\end{array}$ & $\begin{array}{c}0.104 \\
(1.89)\end{array}$ \\
\hline Work-duty 4 & $\begin{array}{l}0.185^{* * *} \\
(3.77)\end{array}$ & $\begin{array}{l}0.165^{* *} \\
(3.16)\end{array}$ & $\begin{array}{l}0.149^{*} \\
(2.34)\end{array}$ & $\begin{array}{l}0.184^{* *} \\
(2.81)\end{array}$ \\
\hline Work-duty 5 & $\begin{array}{l}-0.255^{* *} \\
(-2.63)\end{array}$ & $\begin{array}{l}-0.241^{*} \\
(-2.49)\end{array}$ & $\begin{array}{l}-0.343^{* *} \\
(-3.28)\end{array}$ & $\begin{array}{l}-0.246^{* *} \\
(-3.16)\end{array}$ \\
\hline Age & $\begin{array}{c}0.062 \\
(1.38)\end{array}$ & $\begin{array}{r}0.077 \\
(1.73)\end{array}$ & $\begin{array}{l}0.117^{*} \\
(2.55)\end{array}$ & $\begin{array}{c}0.057 \\
(1.28)\end{array}$ \\
\hline Age squared & $\begin{array}{l}-0.001 \\
(-1.54)\end{array}$ & $\begin{array}{l}-0.001 \\
(-1.87)\end{array}$ & $\begin{array}{l}-0.001 * \\
(-2.51)\end{array}$ & $\begin{array}{l}-0.001 \\
(-1.07)\end{array}$ \\
\hline \multicolumn{5}{|l|}{ Legal status } \\
\hline - married & $\begin{array}{l}1.163^{* * *} \\
(7.53)\end{array}$ & $\begin{array}{l}1.075^{* * *} \\
(7.32)\end{array}$ & $\begin{array}{l}1.042^{* * * *} \\
(6.70)\end{array}$ & $\begin{array}{l}0.927^{* * * *} \\
(6.11)\end{array}$ \\
\hline - divorced & $\begin{array}{c}0.087 \\
(1.05)\end{array}$ & $\begin{array}{c}-0.001 \\
(-0.01)\end{array}$ & $\begin{array}{l}-0.030 \\
(-0.31)\end{array}$ & $\begin{array}{c}-0.014 \\
(-0.15)\end{array}$ \\
\hline - widowed & $\begin{array}{l}-0.076 \\
(-0.52)\end{array}$ & $\begin{array}{l}-0.176 \\
(-1.33)\end{array}$ & $\begin{array}{c}-0.049 \\
(-0.36)\end{array}$ & $\begin{array}{c}0.009 \\
(0.06)\end{array}$ \\
\hline \multicolumn{5}{|l|}{ Number of children } \\
\hline-1 child & & $\begin{array}{c}0.143 \\
(1.66)\end{array}$ & $\begin{array}{l}0.190^{*} \\
(2.00)\end{array}$ & $\begin{array}{l}0.183^{*} \\
(2.04)\end{array}$ \\
\hline-2 children & & $\begin{array}{l}0.241^{*} \\
(2.28)\end{array}$ & $\begin{array}{l}0.296^{* *} \\
(2.63)\end{array}$ & $\begin{array}{l}0.252^{*} \\
(2.22)\end{array}$ \\
\hline-3 children & & $\begin{array}{c}0.083 \\
(0.80)\end{array}$ & $\begin{array}{l}0.237^{*} \\
(2.22)\end{array}$ & $\begin{array}{l}0.205^{*} \\
(1.98)\end{array}$ \\
\hline - 4 or more children & & $\begin{array}{l}-0.297^{*} \\
(-1.97)\end{array}$ & $\begin{array}{c}0.003 \\
(0.02)\end{array}$ & $\begin{array}{l}0.018 \\
(0.13)\end{array}$ \\
\hline \multicolumn{5}{|l|}{ Education } \\
\hline - Primary education & & & $\begin{array}{l}0.878^{* * *} \\
(4.27)\end{array}$ & $\begin{array}{l}0.849^{* * * *} \\
(3.91)\end{array}$ \\
\hline - Some secondary education & & & $\begin{array}{l}1.641^{* * * *} \\
(6.64)\end{array}$ & $\begin{array}{l}1.564^{* * * *} \\
(5.85)\end{array}$ \\
\hline - Secondary education & & & $\begin{array}{l}2.386^{* * * *} \\
(9.52)\end{array}$ & $\begin{array}{l}2.254^{* * * *} \\
(8.53)\end{array}$ \\
\hline - Tertiary education & & & $\begin{array}{l}3.249^{* * *} \\
(11.88)\end{array}$ & $\begin{array}{l}3.096^{* * * *} \\
(10.60)\end{array}$ \\
\hline
\end{tabular}


Table 5 Continued

\begin{tabular}{|c|c|c|c|c|}
\hline & (1) & (2) & (3) & (4) \\
\hline \multicolumn{5}{|l|}{ Primary income source } \\
\hline - Part time work & & & & $\begin{array}{l}-0.801^{* * *} \\
(-6.47)\end{array}$ \\
\hline - Self-employed & & & & $\begin{array}{l}-0.103 \\
(-1.34)\end{array}$ \\
\hline - Retired & & & & $\begin{array}{l}-1.075^{* * *} \\
(-6.50)\end{array}$ \\
\hline - Wife's income & & & & $\begin{array}{l}-1.316^{* * *} \\
(-3.31)\end{array}$ \\
\hline - Student & & & & $\begin{array}{l}-2.130^{* * *} \\
(-7.22)\end{array}$ \\
\hline - Unemployed & & & & $\begin{array}{l}-2.025^{* * *} \\
(-14.13)\end{array}$ \\
\hline - Other & & & & $\begin{array}{l}-1.357^{* * *} \\
(-7.13)\end{array}$ \\
\hline Country dummies & Yes & Yes & Yes & Yes \\
\hline Year dummies & Yes & Yes & Yes & Yes \\
\hline Observations & 13328 & 12904 & 12833 & 12771 \\
\hline
\end{tabular}

t-Statistics in parentheses: $* P<0.05,{ }^{* *} P<0.01,{ }^{* * *} P<0.001$.

opportunities. A third possible channel is that an excessive emphasis on having a job may induce too little risk taking. The obsession of always being self-reliant may lead individuals to avoid risky careers, possibly sacrifying their personal talent for an occupation if the perceived risk of personal failure is relatively large. Similarly, when unemployed, those individuals may take up the first possible job, foresaking the uncertain opportunity of getting a more lucrative one by waiting longer.

\section{Conclusion}

According to a cultural critique, a welfare state with generous social insurance is likely to destroy its own moral basis, i.e. those work norms that are necessary to motivate workers when wage taxes and unemployment benefits are high. While plausible and potentially important, that critique is more fragile than it appears. The cultural critique to the welfare state can be rationalized in theoretical models with optimizing agents. However, as shown in this article, there are counterveiling forces and in some circumstances a more generous welfare state is predicted by theory to strengthen the work ethic of the population. Thus, whether the cultural critique is 
well taken or not is to a large extent an empirical issue. This article has presented some new evidence about it, based on survey data from the OECD countries over the last three decades. With country fixed effects, an increase of social spending as a fraction of GDP is found to have no statistically significant effect on the probability that individuals report a strong work ethic. Across countries, there is a negative correlation between social spending and self-reported work ethic.

From an economic viewpoint, the main reason to be worried about a weak work ethic is its effect upon productivity. This article has empirically explored the link between work norms and income at the individual level. In contrast with existing models and simple intuition, income is not positively correlated with pro-work attitudes in the data. Rather, the relationship between income and work ethic has the form of an inverted U: both a very weak and a very strong work ethic are found to decrease the probability of ranking high in the income distribution. This finding suggests that even if rolling back the welfare state does increase the strength of work norms, income needs not increase as a consequence.

\section{Acknowledgements}

This article is based on a keynote lecture given at the CESifo conference on Employment and Social Protection in Munich in May 2011. I thank the audience and especially Panu Poutvaara for many useful comments and suggestions. This version has also benefitted from comments by an anonymous referee, Frank Neher, András Simonovits, and Paolo Vanin.

\section{References}

Akerlof, G. (1980), "A Theory of Social Custom, of Which Unemployment may be one Consequence", Quarterly Journal of Economics 84, 749-775.

Bertrand, M. and S. Mullainathan (2001), "Do People Mean What They Say? Implications for Subjective Survey Data", American Economic Review 91, 67-72.

Björklund, A. (1993), "A Comparison Between Actual Distributions of Annual and Lifetime Income: Sweden 1951-89", Review of Income and Wealth 55, 303-330.

Bönke, T., G. Corneo and H. Lüthen (2012), "Lifetime Earnings Inequality in Germany", CEPR Discussion Paper DP8929.

Corneo, G. (2011), "Stakeholding as a New Development Strategy for Saudi Arabia", Review of Middle East Economics and Finance 7, 1-19. 
Gradstein, M. (2010), "Social Insurance, Education, and Work Ethics", CEPR DP7838.

Haider, S. and G. Solon (2006), "Life-cycle Variation in the Association Between Current and Lifetime Earnings", American Economic Review 96, 1308-1320.

Halla, M., M. Lackner and F. Schneider (2010), "An Empirical Analysis of the Dynamics of the Welfare State: The Case of Benefit Morale", Kyklos 63, 55-74.

Heinemann, F. (2008), "Is the Welfare State Self-Destructive? A Study of Government Benefit Morale", Kyklos 61, 237-257.

Lindbeck, A. (1995a), "Hazardous Welfare-State Dynamics", American Economic Review 85, 9-15.

Lindbeck, A. (1995b), "Welfare State Disincentives with Endogenous Habits and Norms", Scandinavian Journal of Economics 97, 477-494.

Lindbeck, A. (1997), "Incentives and Social Norms in Household Behavior", American Economic Review 87, 370-377.

Lindbeck, A. and S. Nyberg (2006), "Raising Children to Work Hard: Altruism, Work Norms, and Social Insurance", Quarterly Journal of Economics 101, 1473-1503.

Lindbeck, A., S. Nyberg and J. Weibull (1999), "Social Norms and Economic Incentives in the Welfare State", Quarterly Journal of Economics 94, 1-35.

Lindbeck, A., S. Nyberg and J. Weibull (2003), "Social Norms and Welfare State Dynamics", Journal of the European Economic Association 1, 533-542.

Ljunge, M. (2010), Sick of the Welfare State? Lagged Stigma and Demand for Social Insurance, mimeo, University of Copenhagen.

Moulton, B. (1990), "An Illustration of a Pitfall in Estimating the Effects of Aggregate Variables on Micro Units", Review of Economics and Statistics 72, 334-338.

Mulligan, C. (1997), Work ethic and Family Background, Report for the Employment Policies Institute.

Scruggs, L. and J. Allan (2006), "Welfare-State Decommodification in 18 OECD Countries: A Replication and Revision", Journal of European Social Policy 16, 55-72.

Shelling, T. (1971), "Dynamic Models of Segregation", Journal of Mathematical Sociology 1, 143-186. 


\section{Appendix A}

\section{A1. Proof of Proposition 2}

Without significant loss of generality, assume that all families are ex-ante identical and that the equilibrium has the property that only children with low wage receive a gift both before and after the marginal increase of the tax rate. The individual choice of $s$ leads to

$$
s=\frac{\ln \widetilde{c}_{p}}{\alpha}-\ln \widetilde{c}_{k},
$$

which is Equation (9) in Lindbeck and Nyberg (2006), henceforth LN. Using Equation (3) in LN, one has

$$
\widetilde{c}_{k}=\frac{(1+\alpha)(1-t) w^{h}}{\alpha\left[I+(1-t) w^{l}+B\right]}
$$

and

$$
\widetilde{c}_{p}=\frac{(1+\alpha) I}{I+(1-t) w^{l}+B} .
$$

Define

$$
A(B, t) \equiv \ln \left\{\frac{(1+\alpha)(1-t) w^{h}}{\alpha\left[I+(1-t) w^{l}+B\right]}\right\}
$$

and

$$
Z(t) \equiv \ln \left[\frac{\alpha I}{(1-t) w^{h}}\right] .
$$

Inserting the last four equations into (A.1) and manipulating terms, one can write the work ethic selected by parents as a function of the social insurance parameters:

$$
s=\frac{1}{\alpha}[(1-\alpha) A(B, t)+Z(t)] .
$$

In turn, those parameters must be consistent with individual behavior and the budget constraint of the government,

$$
t\left[\pi w^{h}+(1-\pi) w^{l}\right]=(1-\pi) B,
$$

which is Equation (10) in LN. The fraction of successful children is equal to the individual probability to be successful, $\pi=p$. In turn the latter is 
determined by

$$
\ln \widetilde{c}_{k}+s=\frac{q}{1-p},
$$

which corresponds to Equation (5) in LN. Substituting the last expression in (6) and using the above definitions, one obtains

$$
B=t\left[w^{l}+w^{h} \frac{A(B, t)+s-q}{q}\right] .
$$

For given $t$, Equations (A.2) and (A.4) determine the equilibrium levels of $s$ and $B$. It is straightforward to verify that (A.2) entails a negative relationship between $s$ and $B$, whereas that relationship is positive in (A.4). The associated curves thus intersect once and that intersection corresponds to the unique equilibrium of the model.

In order to derive the effect of a small increase of the tax rate, consider first Equation (A.2). For any given $B$, the effect is

$$
\frac{\partial s}{\partial t}=\frac{1}{\alpha}\left[(1-\alpha) \frac{\partial A}{\partial t}+\frac{\partial Z}{\partial t}\right]
$$

which can be computed as

$$
\frac{\partial s}{\partial t}=\frac{1}{\alpha(1-t)}\left[1-\frac{(1-\alpha)(I+B)}{I+B+(1-t) w^{l}}\right]>0 .
$$

In general, the effect of $d t$ on the curve (A.4) is ambiguous. Thus, consider the case where the tax rate is equal to the one that maximizes the tax revenue. In an interior solution, a small change in the tax rate does not change the tax revenue, which is given by the 1.h.s. of (A.3). Hence, it does not change $(1-\pi) B$. By Proposition 4 in LN, labor market performance $\pi$ decreases in $t$. Hence, a small increase in the tax rate decreases $B$ in equilibrium. Since the curve (A.2) shifts upwards in the $(B, s)$-plane following a small $d t>0$ and since that curve is downwards-sloping, it follows that the equilibrium $s$ must increase strictly. A standard continuity argument shows that the same applies in a sufficiently small interval around the tax rate that maximizes the tax revenue. Q.E.D. 